CATALAN REVIEW

Catalan Review

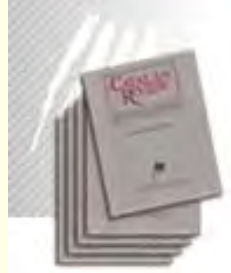

You are accessing the Digital Archive of the Catalan Review Journal.

By accessing and/or using this Digital Archive, you accept and agree to abide by the Terms and Conditions of Use available at http://www.nacs-

catalanstudies.org/catalan_review.html

Catalan Review is the premier international scholarly journal devoted to all aspects of Catalan culture. By Catalan culture is understood all manifestations of intellectual and artistic life produced in the Catalan language or in the geographical areas where Catalan is spoken. Catalan Review has been in publication since 1986 .
NORTH

AMERICAN

CATALAN

SOCIETY
Esteu accedint a l'Arxiu Digital del Catalan Review

A l' accedir i / o utilitzar aquest Arxiu Digital, vostè accepta i es compromet a complir els termes i condicions d'ús disponibles a http://www.nacs-

catalanstudies.org/catalan_review.html

Catalan Review és la primera revista internacional dedicada a tots els aspectes de la cultura catalana. Per la cultura catalana s'entén totes les manifestacions de la vida intel lectual i artística produïda en llengua catalana o en les zones geogràfiques on es parla català. Catalan Review es publica des de 1986.

\title{
Joaquim Xirau: The Philosopher of Love William Kluback
}

Catalan Review, Vol. III, number 1 (1989), p. 109-122 


\title{
JOAQUIM XIRAU: THE PHILOSOPHER OF LOVE
}

\author{
WILLIAM KLUBACK
}

In wonder philosophy is born; the love of wonder is the madness of the philosopher-poet who, in love with love, moves from the mysteries of Diatoma to the wild excesses of Alcibiades and then with Socratic irony wants to comprehend what he knows can only be momentarily grasped and then must be lost. The faces and movements of love are many: with eros we move from the lower toward the higher; with agape from the higher to the lower, but we then ask if there are indeed two separate and distinct moments of that dialectic of love. Is there an upward drive of the soul without that downward embrace that encompasses the soul and carries it toward the force that embraces it; and would there be a loving soul to embrace if love did not already dwell $i$ the lower, able and willing to be encompassed by the love that comes toward it?

By birth neither immortal nor mortal, in the selfsame day he is flourishing and alive at the hour when he is abounding in resource; at another he is dying, and then reviving again by force of his father's nature: yet the resource that he gets will ever be ebbing away; so that Love is at no time either resourceless or wealthy, and furthermore, he stands midway between wisdom and ignorance (Symposium, 203 E. Loeb)

This confounding refusal to be neither identical with the Father's resourcefulness nor the Mother's poverty makes love the neither nor, the Greek notion of privation, the source, of positivity, the realization that in being neither this nor that love, it is the revelation of all that is yet to be and has not yet appeared to be; it is the Being behind being, it is that dynamic which brings forth from being the Being which it is yet to reveal but has not yet revealed. Every being that bears within it the passion of love is wrapped in a Being in which and through which it loves the love with which it is loved. "Loved in the prison of loving you hold us 
enamored with your loves." "Amado, en la prision de amar nos tienes enamorado con tus amores" (Ramon Llull). Our frenzy and reason make us despair of resolving the "love problem"; we want to comprehend, we need to grasp our wonder, and we are anxious with our incapacity to know what can't be known but can only be pondered and thought. Augustine reminds us again and again of the agony of the lower who feels that distance from the beloved.

I cast myself down under a certain fig-tree somehow and gave free rein to my tears and the floods of mine eyes gushed forth, an acceptable sacrifice to Thee. ...

And Thou, O Lord, how long? How long wilt Thou be angry, for ever? Remember not our iniquities of old times, for I felt that I was held by them, I continued to utter my sorrowful cries, "How long, how long, tomorrow and tomorrow? Why not now? Why not an end to my uncleanness this very hour?'” [Confessions Book vir, trans. C.S.C. Williams].

We meditate upon these words and we ask what they mean and we find difficulties because meaning is not enough; we comprehend only in love, only in love with love. Standing in this truth, a contemporary Catalan philosopher asks us to reflect again on love: Joaquín Xirau in I940 wrote Love and World (Amor y Mundo), and it is to his thoughts that we turn to speak again that perennial discourse of love that links us to Plato, Augustine, the poets, the artists, all who are touched with the mystery that Diatoma first showed and then denied us.

Xirau meditates upon that dialectical force which he calls love; he rejects the idea that love goes beyond the individual. "No hay más hombre que el hombre individual» (Obras [Mexico, 1963], 27). Deeply moved by the agape love of St. Paul and St. Augustine, Xirau finds in God's love the supreme moment of that love which from above awakens in the object of love a love that only becomes active when loved. He quotes with approval Fray Luis de Leon that God is the beginning, the middle, and the end, but it also make it difficult for Xirau to comprehend that love 
which Aristotle attributed to the Unmoved Mover, a love that inspired the movement of the universe, a love that caused movement in everything simply because this love existed. It was not a love that went forth and grasped the beloved; it was a love whose very being created movement and love; it was a cosmic love whose existence permeated reality, embraced and encompassed all levels of life, but was not personal and intimate: it was intellectual and encompassing. How do we understand such a love, motivated as we are by our religious traditions and deeply impregnated by the drama of the personal God who loves in spite of our unworthiness and indifference? Aristotle comprehended a love radiating into all and drawing toward itself the truth of every reality. The Unmoved Mover solicits fromm every being the truth of its existence; it draws forth that actualization of potentiality in Which and through which each becomes what essentially it is. The victory - if indeed it is a victory - of Christianity is that belief that "God is the source of all love" (32) and in this love I become what I am: "Por la gracia de Dios soy lo que soy" (Augustine). Xirau implies that in this divine grace Christianity conquered Plato's eros and Aristotle's Unmoved Mover. The dialectic of love, however, knows no victories; it is continual development, embodying in itself every stage of its development. To presuppose that a later stage is higher than a previous one distorts the circular quality of the dialectical thinking which realizes through a later stage the depth and meaning of the earlier. Xirau had a deep sense of the interpersonal, of that corelationship that exists between man and man, and man and God; he knew that it was love that embraced the copartnership that each achieved through the other in the realization of the self. At the core of Xirau's thinking is the fact that in love man fulfills a destiny, through the other this destiny becomes experience, it becomes the embodiment of that dialectic which presupposes in every movement out of the self, toward the other self, there is a return movement by which the self is enlarged and enhanced, becoming more and more the self. "All life is an infinite determined and circums- 
cribed adventure; at every moment, by the infinite circumstances which limit its contours" (134). Infinite and determined, the paradox of the dialectic: infinite in possibility, yet it is determined and individual in every situation. Xirau refused to allow himself to be swept into the abstractness of universality; the source of all reality remained in the individual never to be sacrificed to the logic of abstractions. Xirau had a tenderness for the individual, realizing that love, in bringing individual to individual, deepened the meaning of individuality. He knew that "to live is to transcend, to make of the hypothetical cosmos of knowledge a pulsating microcosmos" (I45). He felt the universe in himself, he felt himself a reflection of the universe; the richness of inner life came not from within, it came from without, from that capacity to take in, to embody, to incorporatem what was outside and to transform and transfigure it in the richness of that inner life, a richness which grew through incorporation, through that movement toward externality. Xirau had the deep insight into the complementary movement of subject moving to object and object moving to subject, each fructifying each other in love. "The true life - the truth of life - is alone fully realized in communion" (I46). True life begins in recognition, that primordial search of life.

Xirau believed that love opened the hiding which each man showed to the other, a hiddenness which we can call the hiding of being, the sadness which we reflect when there is no being to whom we can open our being, the feeling of arbitrariness and aloneness which characterizes that simple being bere, the being anywhere which is indeed a being nowhere. Xirau says:

In love we penetrate into the intimacy of the beloved. The latter reveals its intimacy, its sence and its value, it projects upon the world the splendor of its luminous radiation. ... It is a process of reflection and transfiguration. Reality, without ceasing to be the same, becomes other.... The spirit is projected upon the world and transformed in it with its presence. ... Through its activity we contribute in some measure to its creation.... Reality fuses with us through love; the interest and mutual pene- 
tration of our being and it make of life a pulsating microcosm worthy of the highest respect. Such is the profile of a personality. Every soul bears in its innermost being a world. Only thus do we participate in the community of the cosmos.... To know a person is to discover and illuminate the world which he bears implicitly in his soul [Lo Fugazy lo Eterno, in Obras, 217-I8]

This long statement is worthy in all its detail because it opens to us much of Xirau's dialectical thinking. The movement of love opens man to man, this openness transcends the relationship, projects value, transfigures the fixity of empirical reality and encompasses it in the value which is love, the love that is born in recognition. Love and creation belong together; in love we contribute to what Xirau calls the process of creation. We can read much into this idea because it implies the unfinished nature of creation, of man and of nature. This unfinished quality adds a dynamic dimension to human activity; it makes man a co-creator, reality that correlationship and co-partnership which the divine and the human are increased and enhanced in their mutuality and dependence. If Xirau believed that each of us was a bearer of a world, to be realized and actualized in love, then he comprehended that the pulsating microcosm which is each of us finds its personality throughh relationship with the other microcosms which stand in mutual dependency and need. In the other we find the source of our existence, in us the others find the source of existence; the awareness of the need for recognition is the being of life. "The friend sees in his beloved eternal generation" (Llull, r48).

Again and again, Xirau stresses the need for transcendence.

All reality is immanent, but the intimate structure of immanence is in the capacity for self-transcendence. The being of each being has its ultimate source and fullness in the dynamic projection of its radiating power (I32)

Love is a passion which encompasses and surpasses its own en- 
compassing, but more than a passion, love is an activity, a dialectica integradora which not only drives the self beyond the self, but returns the self to the self in deeper intimacy and knowledge of a self which has surpassed itself. What Xirau insists upon is that this integrating dialectic not become an impersonal process, that is is never freed of that confrontation between man and man, that it is not sublimated nor transfigured in abstraction; the moments of the dialectic are not mechanical, they embody the warmth and intimacy of human relationship from which emerges that comprehension of man as spiritual force moving from sensuality to intellectual comprehension. Man is not only the being who loves, and loves the love with which he is loved; he is also the being who comprehends the meaning of the relationship between the love from above and the love from below, the love which proceeds from the object and the love which arises in the subject. Man is that unique being in whom subject is comprehended as object and object as subject. He is the being who comprehends subjectivity as objectivity and who realizes objectivity as the reality of subjectivity. The integrating dialectic that Xirau exposes makes it possible for us to grasp his sharp and decisive statements which we must then ponder if we want to understand their import and significance. "Every cosmos is, in some measure, a microcosmos" (I28). Yes, we respond to such a declaration, the universe may be mirrored in one of its parts, but this seems at first too easy a reply and we become skeptical about the simplicity of the response. The relationship between cosmos and microcosmos is indeed the relationship between subject and object, between the external and the internal, between the objectivity of subjectivity and the subjectivity of objectivity. The world is transfigured and transformed by every subject that loves and whose love is the ground of knowledge and imagination, the world which in its externality mis estranged from the subject but which becomes part and parcel of the subject if transfigured by it, brought into its subjectivity and transformed by it, becoming its object and the source of its dialectical activity. In each of us in 
whom there is the activity of love this transfiguration and transformation occur and are continuously occurring. The going out and the coming down, the Jacob's ladder of reality, is that perpetual movement which we call the life of the mind. The cosmos is always becoming a microcosmos, and the microcosmos is, in turn, losing itself again into the cosmos. What is significant in Xirau's thought is the meaning of that intergrating dialectic which doesn't unite subject and object and suppresses their distinction, but creates that dynamic tension between them, makes possible the consciousness of each through difference and similarity.

At the core of Xirau's thinking is a process of development and unfolding: "El ser se afirma en el trascenderse y en el distenderse." Being becomes being in transcendence and in enlargement; there is a longing for transcendence, for that capacity to embody in itself the eternal; there is the realization that being becomes being in the openness of self to the other, when being is no longer estranged from what is other to it, does it become conscious of what it is to be; it is an unveiling of the hiddenness of being, it is the purification of the profane state, there is an unlocking of the profane through the embodying and encompassing of what is other to it. Here we delineate that mystery of the holy and the profane and their relationship. The profane is profane only in its hiddenness, in its veilling, in its hiding; being is freed in that integral dialectic of the unveiling of the veiled. Xirau goes on: "Replegarse, detenerse, fruncirse es anequitarse" (I30). Annihilation is return to self, the refusal of openness; it is to conceal or hide, to deny that cosmic dependence and need which is the unveiling of being, to turn away from that movement in which love begins, which is its own realization and the revelation of the mutuality of cosmos and microcosmos. For Xirau the dialectic stands between transcendence and concealment. Here he discovers the movement of love and with it the discourse of knowledge. "The cosmos is a constant germination, a perpetual flowering" (I3I). Poetic terms for that dialectic of love, integrating eros and agape, the above and below, the subject and the object. 
And in the constant flowering, eternal dynamicism, always the same, always diverse, renewal and constant creation, and subject to law; substance and the permanency of being depend upon the capacity to maintain a direction in change, a fundamental path and orientation. God is supreme unity, fundamental and ultimate direction, supreme strength, the ideal eternity [13r].

Again Xirau illustrates his theme, a theme demanding continuous reflection and delineation. Change and similarity strike us as paradoxical, but beyond the apparent paradox there lies a profound truth which Xirau seems hesitant to elaborate. Thought is circular; the wisdom of Aristotle emerges in the realization that the deeper the thought, the deeper the realization of the reality of thinking. Every step which we take forward is a preparation for the realization of what was true at the beginning but only vaguely comprehended in its truth. Every moment of thought is a retaking, reprise, of the previous moment, realizing, sublimating, and bringing to clarity what was in the beginning, the source of thinking. "Siempre el mismo, siempre diverso" terms of contradiction, yet "sometida a ley", subject to that primal dialectic, to that movement of love which is neither agape nor eros, but the revelation of their mutuality, of their oneness in their diversity. We go astray when we sacrifice agape to eros or eros to agape; we lose direction, "un sentido y una orientación fundamental", when we cling to one and disregard the other. Thought is balance, dialectic harmony; the beauty that emerges from that equilibrium between the interdependence of subject and object is a beauty which brings to fruition what is in the one and what is in the other; it is that Beauty which

presides over birth as Fate and Lady of Travail; and hence it is that when the pregnant approaches the beautiful it becomes not only gracious but so exhilarate, that it flows over with begetting and bringing forth, though when it meets the ugly it coils itself close in a sullen dismay... (Symposium 206 D).

In other words, beauty is the actualization of that movement of 
love in which the awareness of subject as the source of transfiguration and transformation meets the object as the source of the awakening and unveiling of subject, as the creation of that dynamic love intercourse which links diversity and similarity. In God the ideal is embodied, but not in a fixed and determined manner; rather, we can speak of God as «dirección fundamental y última". These terms are difficult to comprenhend. What do we mean by "ultimate" and "fundamental", and, in fact, what does "direction" indicate? Only if we continue to comprehend the significance of "dialectica integradora" can the ideal eternity which is divinity be grasped. God is love and intellect; $\mathrm{He}$ is the incarnation of movement, dialectical movement; $\mathrm{He}$ is the beauty which is the source of begetting and procreation, from His Being all movement originates and seeks its source. He is the ideal of love as agape and eros; $\mathrm{He}$ is that integral and integrating dialectic in which and through which subject and object are interdependent and interrelated, reveal themselves through each other, and emerge from that hiddenness where they dwell without each other. God is supreme unity, the ideal of eternity; in this He is the perfection of the dialect of love and knowledge.

All things, real or unreal, possible or impossible, present or absent, actual, past or future, can be integral or external. ... The most distant reality can be for me the most intimate (I40).

In God these conflicts and confrontations are reconciled; in Him they find their harmony. For us they are the tensions, the conflicts which make life the adventure of love, the possibility of order or disorder, the experience of the encompassing or the sadness of concealment. "Nothing is poorer than a closed sould" (I46).

Xirau was convinced that Llull had enunciated a truth when he declared that "love was given us in order to think" (ISI). In this statement Xirau believed that the Hellenic world joined the Christian, the acceptance of the fact that knowledge is rooted in 
love, that truth is the culmination of a profound longing, that wisdom is faith in reason, in the creativity of the imagination, in that strength which drives man toward transcendence, that humility toward the word, the Logos, because it is the word which reveals and enlightens, that bears and mirrors tradition, that links the generations to the generations, that ties immanence to transcendence, man to God. Between the divine and the human stands the woed. "Thou canst see my face" (Exod. 33:20). Immediacy yields to mediacy, love is the neither nor, it is mediation between God and man; this is its mystery, its frenzy, its irony and its humor. No reality can fix and concretize love; it renders all reality free, it loosens all chains, it denies immobility, it affirms movement: the dialectic of eros and agape. Love is also the sufferings of love; she burdens those in whom she dwells, she allows no tranquility, no credal rest; she is always poor and resourceful, never in the possession of anything except in the desire to possess, yet nothing escapes her resourcefullness, she is the possibility of everything and thus the possession of no-thing. Knowledge is more than demonstration, proof, noncontradiction, or syllogistic demonstration; it is dialectical movement, never-ending transformation and transfiguration; it is that insatiable longing for universality which leaves it dissatisfied and unhappy at every stage of its development, it is unending possibility, consciousness of the unfinished nature of all reality. Yet it is the realization that God is real eternity, the perfection and harmony of the divine human corelationship and copartnership which moves thinking toward an ever deeper self-realization, thinking becomes the realization of thinking, as love in love with love becomes an ever deeper embodiment of love. Xirau grasps the essence of both thinking and loving when he enunciates that lapidary but forceful statement: Recordar és re-cordar. Thinking is the retaking of the past into the present, comprehending what at the beginning was abstract and vague but bearing within it what was concrete and actual. Only in the odyssey of thought, in that discourse of reason do we come to understand that the abstractness of the beginnings was also con- 
creteness; every moment of thought is linking through remembrance the other moments of thought, making it possible to manifest what at first was only potential and what in development becomes actual. With this powerful idea Xinau ties his thought to dialectical tradition of philosophy which comprehends thinking historically, grasps reality in development, structures the process of thinking in the movement that goes forward and in the similar movement which turns backward. Like love, which proceeds from the lower to higher and then from the higher to the lower, forever deepening the path of the one and the path of the other, so thought is forever tying the present to the past and the past to the present. Thinking and loving become one in this integral dialectic that links all reality in the dialogue between lover and beloved. "For love all roads are clear, all perspectives illumination" (I6I). Beautifully clarified by Llull: «love lives from thoughts and dies in forgetfulness" (160).

Xirau in one of his last reflections on love identifies it with freedom: "To suppress freedom would be to annihilate love. Love is spirit. And spirit is by definition freedom. There is no morality without love nor love without freedom" ( $\left.16_{3}\right)$. Love is freedom. We are back again to Plato and his comprehension of love as the "passion for immortality", the need "to win eternal mention in the deathless roll of fame, "the desire for "endless fame", the revelation of the longing for eternity which Xirau called the divine, the ideal eternity. The philosophy of love is that transfiguration of mortality into immortality, the exploration and elaboration of man's need to break through to the universal, to the eternal, to the acceptance of the fact that in the mortal there is a longing for the immortal, that mortal life is not the end of all reality, that it stands in tension with transcendence, that man is involved in a continuous overcoming of mortality. In this primordial longing for immortality in mortality man is freedom; no mortal dimension is adequate nor sufficient, each must and should be transcennded; freedom is never-ending transcendence. Xirau bears witness to that depth of that human experience in which and 
through which the divine-human relationship meets in confrontation and corelationship, that meeting of mortality and immortality, that expression of fredom as self-transcendence. The political and moral consequence of this identification of love and freedom is vast; no political ideology, no moral creed is self-sustaining; every historical situation in its realization already bears within it the source of its transcendence. Every attempt to fix and absolutize a historical moment or a moral creed becomes daemonic; the overcoming and surprassing is not a destruction or an elimination; it is a raising to a new level of reality and awareness what was potential in the earlier moment. What is essential is that freedom makes possible the surpassing of every concrete a situation; it is the hope that is embodied in procreation, in that longing not for the beautiful but for the "conception and generation that the beautiful effects". Freedom effects our lives by its very existence; it makes it possible for us to struggle, to believe, to conceive, and to die, it is the source of that activity which denies and refuses to deify the mortal, which prevents the realization of that integral dialectic by which all reality enterns into relationship and copartnership. Xirau correctly follows Hegel and maintains that "pure being is nom-being, to shape its positive and concrete meaning it is necessary to consider being from a transcendental perspective in which value and being, being and value mutually make possible the dialectical unity of life» (ISO). "The dialectical unity of life", with these terms Xirau reaches the conclusion of his thinking on love and world. Love now reveals as dialectic; it is fulfilled in dialectic, but not in a dialectic which is imposed on reality but which the thinking of reality reveals, the objectivity of the dialectic of the subject, the full realization of what Hegel meant when he enunciated that stringent and lapidary statement that subject is object and object is subject. Xirau with his meditations on love has arrived at the same conclusion: the unity of the dialectic of life. Philosphy, Xirau tells us, is not "a Knowledge", but is the basis of all knowledge. 
Every knowledge is a slave of "objectivity".... philosophy is above objectivity. If we take from the word "subjective" all empirical and psychological meaning and give it again its original meaning we can say in all truth that philosophy is in the servicie of "subjectivity". In it it seeks a meaning for all life (Lo Fugaz, 229).

Little commentary is needed to show that with this definition of philosophy Xirau has moved from Plato to Hegel and has arrived at "meditations upon subjectivity", subjectivity which is at the same time objectivity, the dialectic of "the finite in its totality" (E. Weil, "Objective Dialecti», Les Etudes philosophiques, July-Sept. 1970, 344). "There is no dilectic of the understanding. There is only a dialectic of reason, a dialectic not of knowledge, but of thinking, a dialectic of the finite in its totality with the infinite" (ibid., 344). Love and world are no longer held apart from each other; they enter intro relationships with each other; they become through dialectical movement, through the encompassing of from and matter - one reality in which dialectic has surpassed both subject and object and has become one: the discourse of thinking. Xirau has returned philosophy to its origins, to discourse which is neither subjective nor objective, but the source of both in their primordial unity.

Xirau at the end of his work addresses a few remarks to education. "Education is, at the least, respect. ... It is not necessary to impose anything but on the contrary: to liberate personality, take away obstacles, clear paths, awaken interest, open trenches for the fortunes of creative energies" (167). Education is the stimulation of ideas and the appreciation of the tradition which embraces the history of reason, the history of that discourse which encompasses subject and object, eros and agape. "The dialectic of education in all its aspects is a dialectic of love» (170). Eric Weil, who was until recently France's most significant philosopher, has made us aware "that there is no reality beyond discourse; there is no discourse beyond reality" (Weil, 345). Education is the movement toward discourse; it is the love of reason that precedes and establishes all knowledge; it is the presence of love which inspires 
this movement of discourse which is reality, which endeavors to comprehend the oneness of reality and discourse. If education is love, then it is the love of that dialectical unity of life in which we discover what is man, what is that "Objective dialectic of subjectivity", that being whose love unites mortality and immortality, the finite and the infinite. Xirau's work is a rethinking of the great tradition of philosophy, it bears witness to the fact that thinking is remembering and remembering is the linking of past to present and present to past. In thinking that is rethinking we meditate again upon the truths of philosophy. If Xirau makes us think again the oneness of discourse and reality, then he has done what philosophy in its truth must and should always do.

WILLIAM KLUBACK City University of New York 